Professor Emeritus of Sociology; Sherman Paul, Professor of English; the late Allan D. Vestal, Professor of Law; John Boyle, Professor of Religion; John F. Kennedy, Professor of Engineering and Director of the Institute of Hydraulic Research, and Marvin Bell Professor of English and of The Writers' Workshop.

\title{
CREATIVITY IN THE UNIVERSITY-THE IOWA EXPERIENCE
}

These inaugural festivities are taking place on the sixtieth anniversary of an important and widely influential new direction in the program of this university. I refer to a few simple words in the catalogue for 1922_ " "The thesis requirement may be interpreted broadly so as to include artistic production." The background for this innovative step may be found in the growing popularity of courses in creative writing offered by a number of enthusiastic teachers, but the use of the broader term "artistic production," was probably due to the influence of Carl Seashore, Professor of Psychology, who since 1908 had been dean of the Graduate College. Seashore had worked for many years in the psychology of music and had developed a widely used test of musical aptitude. From his position as graduate dean he was able to provide leadership and support for the recognition of creative work in writing, music, and theater. He participated in the appointment of P.G. Clapp to the music department and of E.C. Mabie to the department of speech and dramatic art. By 1922 both these men were already on the faculty and both remained active until the early 1950's. Clapp was composing steadily during these years as well as teaching, conducting, and carrying on administrative duties. Nearly a hundred Ph.D. degrees were awarded during this period, most of them in composition. During Mabie's years, 95 authors wrote 109 long plays and 62 short ones. While he regularly taught playwriting in addition to directing productions at the University Theatre, it was always under the title of Experimental Theatre.

Music and theatre by no means overshadowed writing and the visual arts. In 1929 President Jessup and Dean Seashore were leading figures in the establishment of a School of Fine Arts with Rufus Fitzgerald as director. Fitzgerald lacked credentials as artist or scholar but had gained a reputation at the university as a vigorous and able administrator. It is probable that the general design of an arts campus on the west bank of 
the Iowa River was his conception. He set about raising funds for an art building and gave important assistance to Mabie who had labored for years to build a theatre arts center. Both buildings were dedicated in 1936.

In the same year Lester Longman became head of a reorganized department of art. Grant Wood had already joined the faculty in 1934 as associate professor, a post which he held until his death in 1942. Longman set out to develop a program in which students would become both professionally competent and well educated. He observed that "art schools prepared good artists who were poor historians and generally uneducated. Universities prepared good historians and poor artists." An important part of the new program was the opportunity to do studio work for an advanced degree. During the next few years an impressive list of well-known artists was added to the faculty, and by 1945 the art department had more graduate students than any other such program in the country.

In this highly abbreviated space the general form of the Iowa experience in creative work has become fairly clear. It was a most striking combination of talent and leadership. To list all the names of those who played important roles is not possible and would probably be confusing if it were. Thus P.G. Clapp symbolizes scores of performers and composers, Mabie a long roster of actors, directors and playwrights, and Longman an equally notable line of painters, sculptors, printmakers and others in ceramics, photography, and design. In the same way, Paul Engle symbolizes writing. He wrote a volume of poems for his M.A. thesis and was heir to the longest tradition of creative work in Iowa when he became director of The Writers' Workshop in 1941. Four years before he retired in 1965 to direct the International Writing Program, Engle paid eloquent tribute to those who had made the Iowa experience possible. Perhaps taking his cue from Taine's famous formula-la race, le milieu, le moment-he wrote of "The Writer and the Place" in an introduction to Midland, an Anthology of Poetry and Prose:

This book is the result of a vision.

By vision, I do not mean the abrupt and ecstatic experience of Saul on the road to Damascus, blinded by a light "above the brightness of the sun," and startled by a voice speaking from heaven.

By vision, I mean the steady development at the University 
of Iowa of the conviction that the creative imagination in all of the arts is as important, as congenial, and as necessary, as the historical study of all the arts. How simple, and yet how reckless.

This gradual revelation was quite as astonishing as a sudden idea seen, for the first time, in a flash of light. It took imagination, some years ago, for an educational institution to put its trust in the imaginative arts. Logical as the theory that it is as proper to encourage the writing of a good poem as the study of a bad one (or even of a good one) might sound, what would really happen when the poets arrived? Were they not traditionally doubtful types, likely to turn up wearing a nest of robins in their hair?

If Iowa was the place, the 1930s was the time. It was in this decade that John Dewey was invited to give the William James lectures at Harvard, and the result was a book we know under the title Art as Experience, published in 1934. Dewey deplored the chasm between ordinary and esthetic experience which tends to locate art in the library, the museum, and the concert hall. When a Time writer said that at Iowa it was believed "that the way to learn about art was to produce it," he might have been quoting freely from Dewey. So might Allen Tate when he observed that "We study literature today from various historical points of view, as if nobody ever intended to write any more of it."' This clearly implies that more of it ought to be written and that the university is a place where it ought to be done. Dewey emphasized repeatedly that the full experience of art must include doing as well as undergoing, expression as well as response, creativity as well as history and criticism. This does not suggest that historical and critical studies should be abandoned but rather that these efforts may be carried on most successfully at a place where creative work also is being done.

Dewey's view is clear enough with respect to the individual but less so with respect to an organization or a whole society. Recognition of creative work in the unversity does not automatically answer the question of how it is to be judged and by whom. In their quest for an answer to this question, universities that have followed the Iowa exam-

'Time and Tate are both quoted by Stephen Wilbers, The Iowa Writers' Workshop, The University of Iowa Press, Iowa City, 1980, pp. 59 and 62. 
ple have gradually developed a new academic role, that of the artistteacher. Defining the credentials and responsibilities for such a person has not been easy. Should the teacher impose his own style, her own style, on the student? This was common in the Renaissance workshop where, for so long as the articles of apprenticeship lasted, the master could sell the pupil's work as his own. Rumors were circulated at Iowa that Grant Wood did exactly that. And when artist-teachers do their own creative work who is to judge it, fellow artists or historians and critics?

These questions are not new. They were brought up at the beginning of the French Revolution when there was an effort to make a clean break with the old regime in the arts as well as in government. The artist had once been a craftsman who learned his craft in the guild system and did his work to please a patron. In France, the guild system had gradually been absorbed by academies under the direction of the monarchy. The Revolution was to abolish this system and artists were searching for someone who would issue their declaration of independence. As it happened,

the most famous artist of the period, Jacques Louis David, was also an able politician and administrator.... For the first time, artists, as a group, were involved in politics and the fight for freedom of expression. The repercussions of David's speech before the Assembly in 1790 are still being felt. David discussed the importance of the arts to the Revolution and the incompatibility of the Academy's policies with the new spirit of Reason and the Constitution. He called for the establishment of a self-governing Commune of the Arts. This speech was the first public statement by an artist of the political and social utility of the arts under a government based on consent. ... David's reforms drew the lines of battle. Who is competent to judge the merit of a work of art? Should the public patron focus on diffusion [popularity] or quality? What do artists mean when they demand recognition? What exactly is creative freedom??

David eventually decided that artists are not necessarily the best 
judges of their own work and that of their colleagues. In 1793 he wrote,

to leave the judgment of the productions of genius to artists alone would be to leave them in the rut of habit in which they crawled before the despotism they flattered.... Thus, he who is gifted with a fine sensibility, though without culture [training], and the philosopher, the poet and the scholar... are the judges most capable of representing the tastes and insights of the entire people. (Fox, 140)

It is easy to read this opinion and decide that David had become a conservative in three short years. But it is in the final two words that the spirit of revolution is captured. Art is no longer the property of the patron but of the "entire people."

It is not difficult to transpose David's questions and answers to a university setting. Should creative work by students be judged by artist-teachers only, or also by scholars and critics? This question was never faced directly by innovators at Iowa. The battle was to win acceptance of creative work for thesis credit. It would have been premature to try to alter at the same time the whole structure of graduate education. To my knowledge, it was never proposed. At the beginning of the new system there were few, if any, artist-teachers on the faculty. Scholars trained in traditional ways composed the committees which judged the creative work of students. When artist-teachers were added to the faculty they could serve as thesis advisors and committee members without basic changes in the rules.

An additional step was necessary to make artist-teachers eligible for promotion and tenure-the acceptance of their own creative work in the place of traditional scholarly and scientific research. When this step was taken, the question of who is competent to judge the work of a faculty artist was almost the same as it was in David's day. If artists are not the best judges of the work of their colleagues, then who shall judge? In practice it has proved relatively easy to adapt an old system to a new situation. The system is primarily an administrative one in which administrators make judgments about work of many kinds in addition to the kind of work they have done themselves. Perhaps we depend on the administrator to be gifted, as David suggested, "with a fine sensibility though without training."

The artist-teacher who becomes a professor with tenure is in a patronage relation with the university and perhaps, from the point of 
view of the artist, it is the most generous system of patronage in the history of art. But there may be a flaw in this best of all worlds to date. Suppose the artist and his counterparts in other universities form associations after the pattern of learned societies of scholars and scientists, and in these societies they write, compose, and paint for each other rather than for a public. When this occurs, what has become of David's ideal of art as the heritage of "the entire people?" If this is indeed a problem, it is not limited to the arts. It is one that is shared with the entire university. If it is legitimate to ask who a poem is for, or a painting or a piece of music, it is equally legitimate to raise similar questions about the work done in the library or the laboratory. It would be less than a happy ending to the story of creative work in the arts on campus if the result were that art belongs primarily to those who create it and only in a secondary way to the rest of the population.

A somewhat different outcome is possible. Scholars and scientists in universities have argued powerfully that their work can be done most effectively in a protective environment with expensive resources and the safeguards of tenure. The result is a great deal of social and intellectual distance between universities and the public which supports them. We have had glimpses of the same kind of isolation developing in the arts. It may well be that the arts include a broader sense of the public than most other advanced studies, and this may be the reason for our feeling ill at ease when the life of the artist is more and more modeled on the life of the scholar or scientist. This feeling may lead to not only a re-evaluation of art in the university but also to a serious examination of the relation of the public to the whole enterprise of higher education. Such an outcome was certainly not in the minds of those who argued for the recognition of creative work sixty years ago at Iowa, but important changes nearly always have unanticipated consequences.

J. Richard Wilmeth

\section{THE LIFE OF THE MIND}

I was about to ask how would we know if a university were fostering and furthering the life of the mind, but I see that it would be better to ask whether or not the university fostered and furthered my life of the mind. You will forgive the presumption, but all of us have a life of the 